\title{
Age and productivity of the Antarctic scallop, Adamussium colbecki, in Terra Nova Bay (Ross Sea, Antarctica)
}

\author{
Olaf Heilmayer $^{\mathrm{a}, *}$, Thomas Brey ${ }^{\mathrm{a}}$, Mariachiara Chiantore ${ }^{\mathrm{b}}$, \\ Riccardo Cattaneo-Vietti ${ }^{b}$, Wolf E. Arntz ${ }^{\mathrm{a}}$ \\ a Alfred Wegener Institute for Polar and Marine Research, P.O. Box 120161, Columbusstrasse, \\ 27568 Bremerhaven, Germany \\ ${ }^{\mathrm{b}}$ DIPTERIS, University of Genoa, Corso Europa, 26, 16132 Genoa, Italy
}

Received 1 October 2002; received in revised form 6 December 2002; accepted 31 December 2002

\begin{abstract}
Body size, geographical distribution, and biomass make Adamussium colbecki (Smith, 1902) one of the most conspicuous bivalve species in the Antarctic. Based on samples collected in austral summer 1999/2000 in Terra Nova Bay, the annual formation of shell growth bands visible on X-ray photographs was verified by stable isotope analysis. A general von Bertalanffy growth function was fitted to size-at-age data of 25 individuals $\left(H_{\infty}=108.86 \mathrm{~mm}, K=0.114\right.$ year $^{-1}, t_{0}=-0.367$, $D=1.284$ ). Somatic production calculated from mass-specific growth rates was $234.6 \mathrm{~kJ} \mathrm{~m}^{-2}$ year $^{-1}$. Gonadal productivity amounted to $70.92 \mathrm{~kJ} \mathrm{~m}^{-2}$ year ${ }^{-1}$. Annual somatic and gonad production-to-biomass ratios $(P / B)$ were 0.199 and 0.052 , respectively. According to its consumption and production, $A$. colbecki is likely to play a significant role in the trophic web of Terra Nova Bay.

(C) 2003 Elsevier Science B.V. All rights reserved.
\end{abstract}

Keywords: Antarctic scallop; Bivalvia; Pectinidae; Production; Stable isotope analysis

\section{Introduction}

In contrast to temperate benthic environments (e.g. Loo and Rosenberg, 1989; Wildish and Kristmanson, 1997; Mistri et al., 2001), molluscs contribute little to the often

* Corresponding author. Tel.: +49-471-4831-1320; fax: +49-471-4831-1149.

E-mail address: oheilmayer@awi-bremerhaven.de (O. Heilmayer). 
extraordinarily high benthic standing stock in Antarctic waters (Arntz et al., 1994; Brey and Gerdes, 1997) and are generally thought to play a minor role regarding energy flow (JarreTeichmann et al., 1997). Locally, however, some populations may reach considerable abundances and may play a significant role in nutrient cycling and benthic-pelagic coupling.

In nearshore waters of the Ross Sea, the endemic scallop Adamussium colbecki (Smith, 1902) is the most abundant bivalve down to 100-m depth (Chiantore et al., 2001). A. colbecki 'banks' play an important role in the coastal food web as they process up to $14 \%$ of the total carbon flux (Chiantore et al., 1998) and represent an important food source for higher tropic levels, e.g. fish (Trematomus bernacchii Boulenger) and invertebrates such as Neobuccinum eatoni (Smith, 1875) and Paraborlasia corrugata (McIntosh, 1876) (Vacchi et al., 2000). Despite its widespread distribution and assumed significance for the system's energy flow (e.g. Stockton, 1984; Berkman, 1990; Albertelli et al., 1998; Chiantore et al., 1998, 2001), little is known about the population dynamics and production of this species.

This study presents the first reliable age determination of $A$. colbecki from Terra Nova Bay as confirmed by stable isotope analysis. Based on these data, production and productivity values are calculated in order to evaluate the significance of $A$. colbecki in the trophic web and energy flow of the coastal Ross Sea ecosystem.

\section{Materials and methods}

\subsection{Sampling and processing of samples}

Specimens were collected in Terra Nova Bay ('Road Cove', $74^{\circ} 41.9^{\prime} \mathrm{S}, 164^{\circ} 07.5^{\prime} \mathrm{E}$ ) in austral summer 1999/2000 at 30- to 76-m depth by Charcot-Picard and naturalist dredge. Shell height (defined as the maximum distance between the dorsal hinge and ventral margin) of a representative subsample of 895 individuals was measured to the nearest 0.1 mm using vernier callipers. A size frequency distribution (SFD) was obtained by pooling individuals using class intervals of 2-mm size. Additional size frequency data from the same site, obtained with the same gear, have been provided by Chiantore et al. (2000), Cattaneo-Vietti et al. (1997), and references therein. To remove the fluctuations between years and obtain a more representative long-term 'average' population, a multiyear size frequency distribution was constructed by pooling data taken from the years 1989/1990 to $1999 / 2000$. Prior to pooling, each sample was converted into percentage values to give the same weight to each sample.

Size-mass relationships were modeled by linear regression of:

$$
\log (M)=\log (a)+b \log (\mathrm{SH})
$$

where $M$ is the soft tissue mass $(\mathrm{g})$ at shell height $\mathrm{SH}(\mathrm{mm})$. Gonad colouring was used to determine sex of the individuals (Chiantore et al., 2002). Soft tissue dry masses (DM) were determined by oven drying of tissues at $60{ }^{\circ} \mathrm{C}$ for $24 \mathrm{~h}$. 


\subsection{Age and growth}

Traditional methods of ageing $A$. colbecki such as counting bands on the shell surface (e.g. Stockton, 1984; Berkman, 1990) or on X-ray photographs (Ralph and Maxwell, 1977; Cattaneo-Vietti et al., 1997) are not reliable without validation of annual formation of those bands, as shown for scallops in general by Krantz et al. (1984) and Dare and Deith (1990). We identified and verified annual growth bands in A. colbecki shells in a three-step procedure: (i) external growth band identification, (ii) comparison with internal growth band pattern, and (iii) validation of annual formation by stable isotope analysis.

In this study, only undamaged upper (left) shell valves free of epibionts were used for growth analysis. Prior to analysis, shells were cleaned of organic matter with warm $5 \%$ $\mathrm{NaOCl}$ solution, washed with $96 \%$ ethanol, rinsed with water, and dried at $60{ }^{\circ} \mathrm{C}$ for $12 \mathrm{~h}$. External, macroscopically visible shell surface growth bands were identified following the method described by Merrill et al. (1965). This visual growth band pattern was compared with the pattern of conspicuous rings of higher density detected on X-ray photographs of the same shells. X-rays were taken by a Hewlett Packard Faxitron 43855 mammograph with fixed anode, using an AGFA-Strukturix D4 FW film and the following parameters settings: focal film distances $45 \mathrm{~cm}$, voltage 30 to $45 \mathrm{kV}$, exposure times 35 to $80 \mathrm{~s}$. To test whether or not identified growth bands are formed annually, we analyzed stable isotopes of shell carbonate (for review, see Richardson, 2001). This approach has recently been applied successfully to identify annual growth patterns of Antarctic invertebrates (e.g. Marshall et al., 1996; Brey and Mackensen, 1997) and of various scallops (e.g. Krantz et al., 1984; Tan et al., 1988; Dare and Deith, 1990; Lasta et al., 2001). Stable oxygen ratios $\left(\delta^{18} \mathrm{O}\right)$ are inversely related to temperature (Epstein et al., 1953), hence lower $\delta^{18} \mathrm{O}$ characterises shell parts deposited during spring/summer, whereas higher values correspond to parts formed during autumn/winter. Isotope analyses were performed on five representative specimens (largest individual: $87-\mathrm{mm}$ shell height). Calcium carbonate powder was sampled from the outer shell layer in equally spaced $(\sim 1 \mathrm{~mm})$ dorso-ventral series using a small dental drill (bit size: $0.5 \mathrm{~mm}$ ). $\delta^{18} \mathrm{O}$ were determined with a Finnigan MAT251 mass spectrometer coupled to an automatic carbonate preparation device. The results were reported in mil (\%o) deviations related to the Pee Dee belemnite (PDB) standard through repeated analyses of National Bureau of Standard (NBS) isotopic reference material 19 (Hut, 1987). The precision of measurements was better than $\pm 0.08 \%$, based on routine measurements of a laboratory-working standard.

On confirmation of annual formation of X-ray visible growth bands, shells of 25 individuals of $A$. colbecki (15 males, 10 females) were X-ray photographed. Number (i.e. age) and corresponding SH of each detectable X-ray growth band in each shell were recorded. A generalized von Bertalanffy growth model (gVBGF) was fitted to the resulting 185 size-at-age data pairs by an iterative nonlinear least-square method (Newton algorithm, see Brey, 2001 for details):

$$
H_{t}=H_{\infty}\left(1-\mathrm{e}^{-K(t-t o)}\right)^{D}
$$

where $H_{t}$ is shell height at time $t, H_{\infty}$ is mean asymptotic shell height, $K$ is the Brody growth coefficient, $D$ determines the shape of the curve (inflection point if $D>1$ ), and $t_{\mathrm{o}}$ is the age when shell height equals zero. 


\subsection{Production}

Somatic production of soft tissue $\left(P_{\mathrm{S}}\right)$ was calculated by the mass-specific growth rate method according to Crisp (1984) and Brey (2001) from the SFD, the VBGF parameters, and the appropriate size-mass relation:

$$
P_{\mathrm{S}}=\sum N_{i} M_{i} G_{i}
$$

where $N_{i}$ and $M_{i}$ are the number of bivalves and mean individual somatic mass in size class $i$, respectively, and $G_{i}$ is the annual mass-specific growth rate which is computed by

$$
G_{i}=b K\left(H_{\infty}-H_{i}\right) / H_{i}
$$

where $b$ is the exponent of the size-mass relation (Eq. (1)), $K$ and $H_{\infty}$ are parameters of the von Bertalanffy function (Eq. (2)), and $H_{i}$ is the mean height in size class $i$.

Since $A$. colbecki has a discrete reproductive cycle and spawns only once a year (Berkman et al., 1991), gonad production per total sample $\left(P_{\mathrm{G}}\right)$ was estimated by the decline of gonad mass before (summer) and after spawning (winter):

$$
P_{\mathrm{G}}=\sum N_{i}\left(M_{\text {gonad (summer) }}-M_{\text {gonad (winter) }}\right)
$$

where $N_{i}$ is the number of bivalves in size class $i$ and $M_{\text {gonad (summer) }}$ is the mean individual gonad mass in summer in size class $i$. $M_{\text {gonad (winter) values in this study were obtained }}$ from a linear regression calculated from measurements of some individuals maintained under simulated winter conditions in aquaria at the AWI (Germany, Bremerhaven):

$$
\log M_{\text {gonad }(\text { winter })}(\mathrm{g} \mathrm{DM})=-6.342+2.52 \log \mathrm{SH}(\mathrm{mm})
$$

Annual production/biomass ratios were calculated from somatic production $\left(P_{\mathrm{S}}\right)$, gonad production $\left(P_{\mathrm{G}}\right)$, and biomass per total sample $\left(B_{\mathrm{S}}=\Sigma N_{i} M_{i}\right)$. Annual production of $A$. colbecki per square metre was calculated by multiplying the production-to-biomass $(P / B)$ ratios with an estimate of average biomass derived from mean body mass per total sample and mean abundance at the sampling site $\left(60\right.$ individuals $\mathrm{m}^{-2}$; Cattaneo-Vietti et al., 1997).

The following conversion factors were used:

1 g somatic $\mathrm{DM}=20.22 \mathrm{~kJ}$ (Brey et al., 1988).

$1 \mathrm{~g}$ gamete $\mathrm{DM}=23.4 \mathrm{~kJ}$ (average according to MacDonald and Thompson, 1985).

$1 \mathrm{~g} C_{\text {org }}=45.7 \mathrm{~kJ}$ (Brey, 2001).

\section{Results}

\subsection{Morphometrics}

Size frequency distribution for several austral summers (Fig. 1a-g) showed a high persistency of large individuals $(>60 \mathrm{~mm})$, with large oscillations in the smaller size 


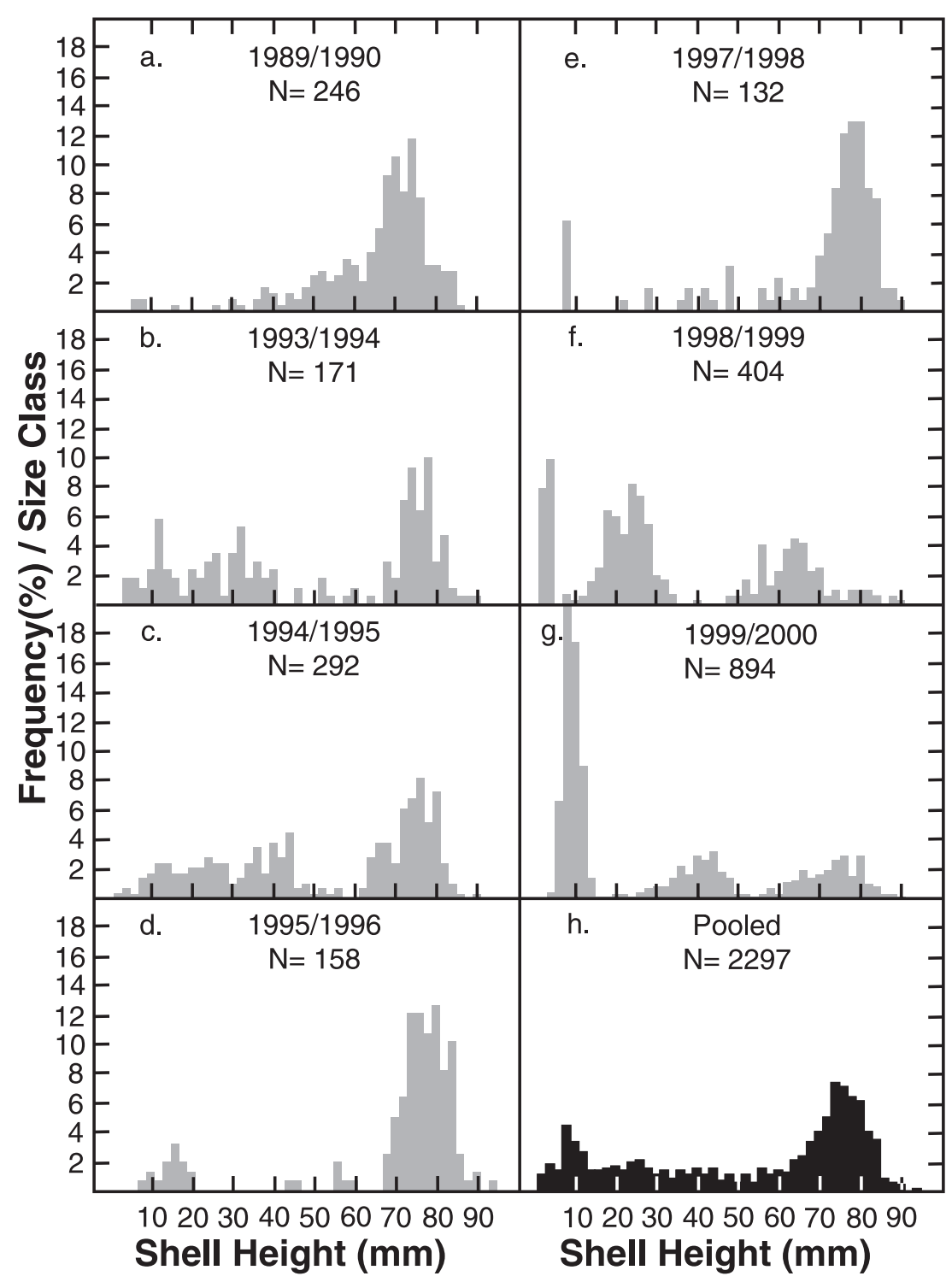

Fig. 1. A. colbecki. Size frequency distribution in Terra Nova Bay ('Road Cove') using class intervals of $2 \mathrm{~mm}$ : ( $a$ and b) in austral summer 1989/1990, 1993/1994 (redrawn from Cattaneo-Vietti et al., 1997), (c and d) in austral summer 1994/1995, 1995/1996 (redrawn from Chiantore et al., 2000), (e) in austral summer 1997/1998 (Chiantore and Cattaneo-Vietti, unpublished data), (f) in austral summer 1998/1999 (redrawn from Chiantore et al., 2001), (g) in January 2000, and (h) pooled samples (1989/1990 to 1999/2000). 
classes $(<30 \mathrm{~mm})$. The multiyear size frequency distribution (Fig. 1h) was polymodal and dominated $(>50 \%)$ by large animals $(>66 \mathrm{~mm})$.

Mean soft tissue $\mathrm{DM}$ was $1.35 \mathrm{~g}(\mathrm{SD}=1.4 \mathrm{~g})$ with a range from 0.12 to $5.2 \mathrm{~g}$. A slight but significant difference (ANCOVA: $P=0.011, N=165$ ) in size-soft tissue DM relation was found between males $(\log (\mathrm{g} \mathrm{DM})=2.882 \log (\mathrm{mm} \mathrm{SH})-4.832)$ and females $(\log (\mathrm{g} \mathrm{DM})=2.882 \log (\mathrm{mm} \mathrm{SH})-4.836)$. As the sex ratio was nearly $1: 1$, we did not differentiate between sexes and used the overall equation $\log (\mathrm{g} D M)=2.882 \log$ $(\mathrm{mm} \mathrm{SH})-4.837$ for all subsequent calculations. The relation between gonad dry mass and shell height was not significantly different between male and female animals (ANOVA of log-transformed data, $P>0.5$ ) and can be described by the overall equation:

$$
\begin{aligned}
& \log M_{\text {gonad }} \text { (summer) }(\mathrm{g} \mathrm{DM})=-8238+4.058 \log (\mathrm{mm} \mathrm{SH}) \\
& N=69 ; \quad R^{2}=0.89 ; \quad P<0.01
\end{aligned}
$$

\subsection{Age and growth}

X-ray bands could clearly be distinguished up to $80-\mathrm{mm}$ shell height; further growth bands closer to the shell edge could not be resolved accurately and were hence not included in the analysis. A comparison of external vs. X-ray bands showed a high degree of consistency $(89.4 \%)$ in total number of growth bands, whereas the position of external and X-ray band differed quite often (up to $2 / 3$ of all bands in one shell).

Fig. 2 shows X-ray photographs and corresponding $\delta^{18} \mathrm{O}$ profiles of two representative $A$. colbecki shells from Terra Nova Bay. $\delta^{18} \mathrm{O}$ values ranged from $3.04 \%$ to $3.88 \%$ o (Fig. 2b) and $3.13 \%$ to $3.92 \%$ (Fig. 2d) over the scallops lifetime, showing a cyclical pattern with a slight trend towards lower values with increasing height. Eighty-five percent of all X-ray growth bands coincide spatially with a local $\delta^{18} \mathrm{O}$ peak (Fig. 2a and b), indicating that these bands were formed at times of lowest temperature. The 185 sizeat-age data pairs obtained from X-rays were fitted best by a general von Bertalanffy equation (Fig. 3)

$$
H_{t}=108.86 \mathrm{~mm}\left(1-\mathrm{e}^{-0.114(t+0.367)}\right)^{1.284} \quad R^{2}=0.983
$$

The analysis of the residuals of this model showed no significant differences in growth between males and females. The oldest individual found was estimated to be 18 years old (91.8-mm height), but maximum age is likely to be higher.

\subsection{Production and productivity}

Total annual production for the season $1999 / 2000$ amounted to $14.63 \mathrm{~g} \mathrm{DM} \mathrm{m}^{-2}$ year $^{-1}\left(305.51 \mathrm{~kJ} \mathrm{~m}^{-2}\right.$ year $\left.^{-1}\right)$, corresponding to an annual $P_{\text {tot }} / B$ ratio of 0.251 ( 0.199 for soma and 0.052 for gonads). Individuals $>60 \mathrm{~mm}$ contributed most to somatic as well as gonad production of the population (Fig. 4b). Mean annual 

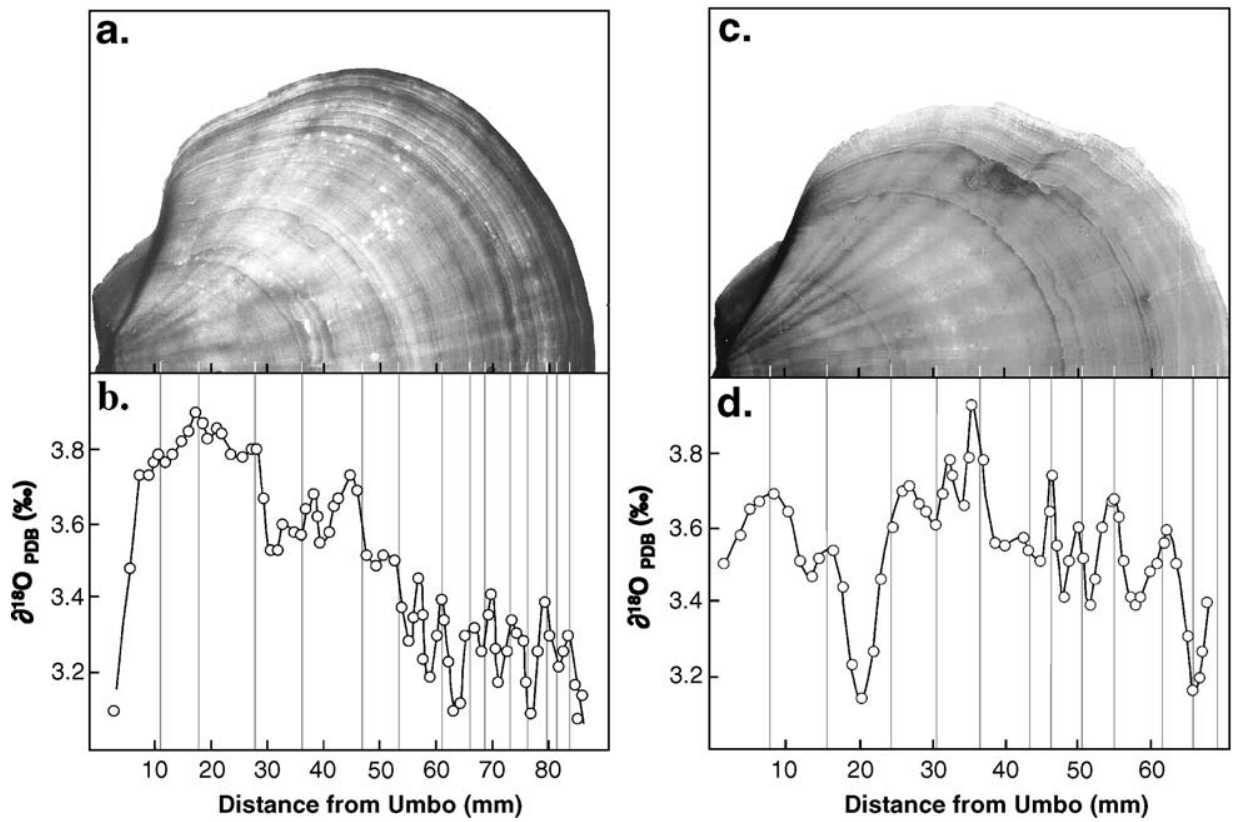

Fig. 2. A. colbecki. X-ray photographs ((a) $87.1 \mathrm{~mm} \mathrm{SH}$, (c) $72.1 \mathrm{~mm} \mathrm{SH}$ ) and corresponding stable oxygen isotope ratio profiles ((b) 74 samples, (d) 62 samples) of two specimen. Grey bars indicate internal growth bands. $\delta^{18} \mathrm{O}$ is plotted as weighed moving average $\left(\left(x_{1}+2 x_{2}+x_{3}\right) / 4\right)$.

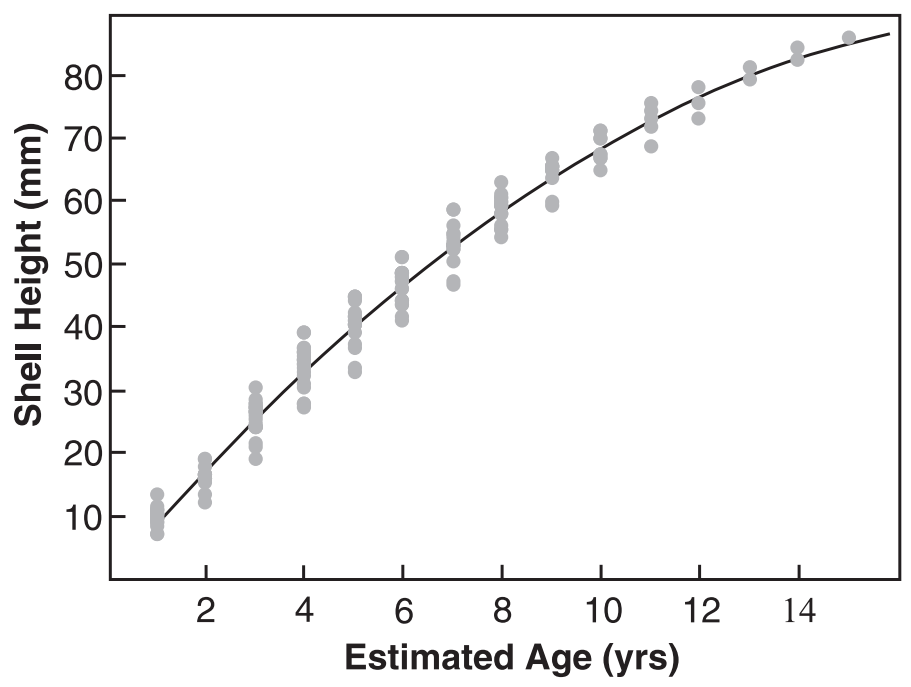

Fig. 3. A. colbecki. General von Bertalanffy growth function fitted to size-at-age data obtained from $25 \mathrm{X}$-ray photographed shells. Growth function parameters are $H_{\infty}=108.86 \mathrm{~mm}, K=0.114, D=1.284$, and $t_{0}=-0.367$ $\left(N=185, R^{2}=0.983\right)$. 
biomass of $A$. colbecki was estimated to be about $58.34 \mathrm{~g} \mathrm{DM} \mathrm{m}^{-2}(1179.64 \mathrm{~kJ}$ $\mathrm{m}^{-2}$ ). From the multiyear size frequency distribution (1989-2000), average biomass, somatic tissue, and gonad production were calculated to be $134.46 \mathrm{~g} \mathrm{DM} \mathrm{m} \mathrm{Dm}^{-2}$ $\left(2718.78 \mathrm{~kJ} \mathrm{~m}^{-2}\right), 21.57 \mathrm{~g} \mathrm{DM} \mathrm{m}^{-2}$ year $^{-1}\left(432.81 \mathrm{~kJ} \mathrm{~m}^{-2}\right.$ year $\left.^{-1}\right)$, and $7.54 \mathrm{~g}$ $\mathrm{DM} \mathrm{m}{ }^{-2}$ year $^{-1}\left(176.47 \mathrm{~kJ} \mathrm{~m}^{-2}\right.$ year $\left.^{-1}\right)$, respectively. Annual $P_{\text {tot }} / B$ ratio amounted to 0.215 .

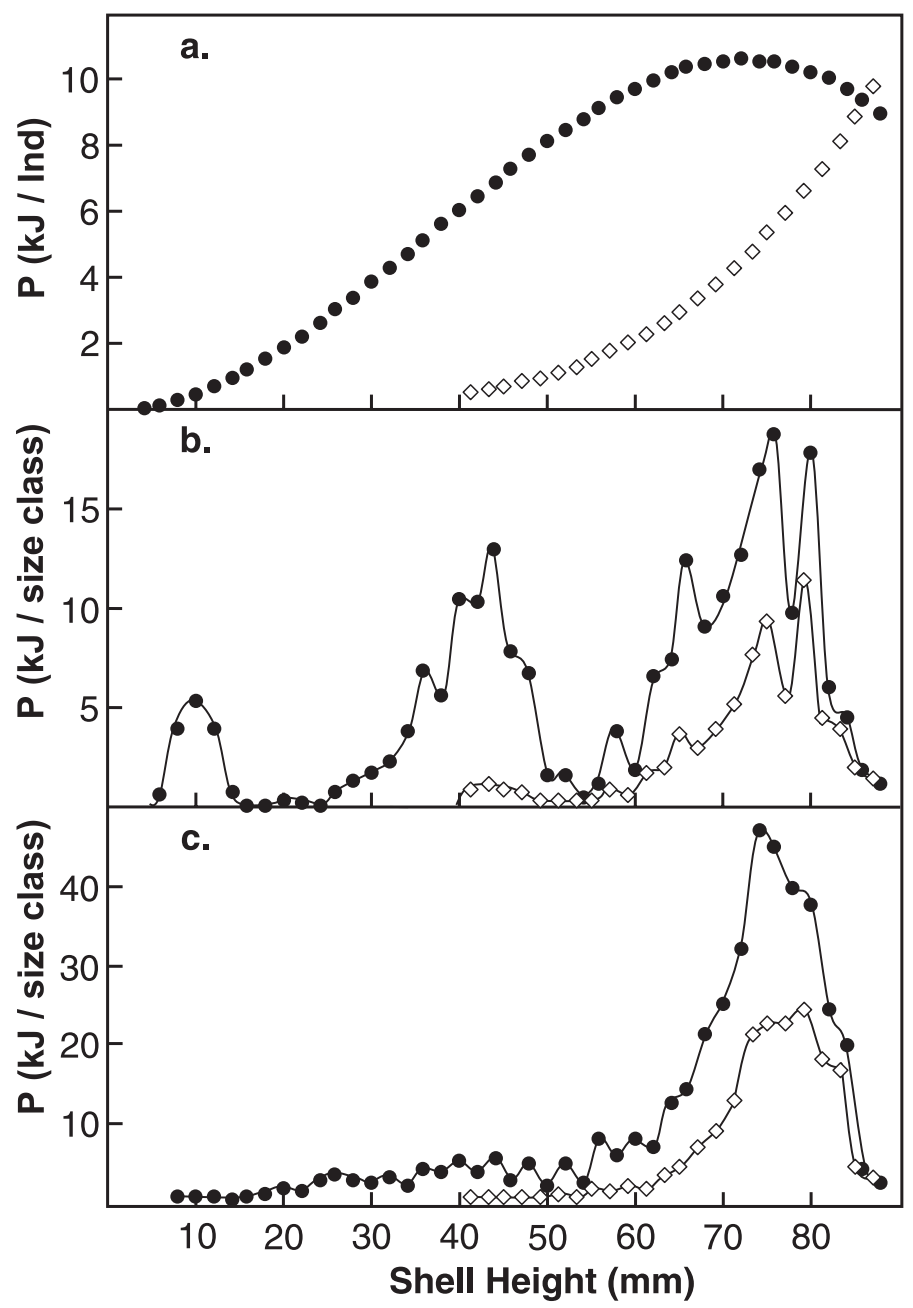

Fig. 4. A. colbecki. (a) Individual production of somatic tissues and individual gonad production for different size classes. (b) Size-specific distribution of annual somatic tissues and gonad production at the population level, based on SFD from austral summer 1999/2000. (c) As in (b) but based on the multiyear SFD 19892000 . 


\section{Discussion}

\subsection{Age determination}

The general correlation between changes in seawater temperature and changes in shell $\delta^{18} \mathrm{O}$ has already been demonstrated for molluscs living at temperatures close to $0{ }^{\circ} \mathrm{C}$ (Marshall et al., 1993; Simstich et al., 2001), as well as for A. colbecki in particular (Barrera et al., 1990; Lohmann et al., 2001). Maximum $\delta^{18} \mathrm{O}$ amplitudes in the scallops investigated here correspond to an annual temperature range of about $2.6{ }^{\circ} \mathrm{C}$ (Craig palaeotemperature equation, cf. Marshall et al., 1993), which is in good agreement with the observed seawater temperature range of -1.8 to $+0.75{ }^{\circ} \mathrm{C}$ in the Ross Sea (Picco et al., 2000; Povero and Petrillo, 2000). The slight overall trend to lower $\delta^{18} \mathrm{O}$ values with increasing size and shell height up to $50 \mathrm{~mm}$ (Fig. $2 \mathrm{~b}$ and d) is not uncommon in molluscs (e.g. Krantz et al., 1987; Weidman et al., 1994; McConnaughey et al., 1997). Such trends may be related to a continuous change in the relation of somatic to gonad production with age (Calow, 1983) and/or to metabolic changes at onset of sexual maturity (Chiantore et al., 2000).

A mark-recapture study recently conducted in Terra Nova Bay and in the aquaria of the Alfred Wegener Institute in Bremerhaven (Chiantore et al., in press) indicates that annual growth increments in $A$. colbecki are $\geq 1 \mathrm{~mm}$ up to about 75-mm shell height and 15 years of age. Therefore, the 1-mm spatial resolution of our isotope shell transects seems to be sufficient to resolve intra-annual $\delta^{18} \mathrm{O}$ oscillations within this size and age range.

The annual water temperature cycle is assumed to be the major determinant of shell $\delta^{18} \mathrm{O}$. Salinity fluctuations can change water $\delta^{18} \mathrm{O}$ and hence may also affect shell $\delta^{18} \mathrm{O}$, but this effect is of minor significance (Tan et al., 1988). Moreover, salinity fluctuations caused by ice formation and melting affect $\delta^{18} \mathrm{O}$ in the same directions as temperature (Barrera et al., 1990) and hence will enhance the isotope signal. The annual water temperature cycle at Terra Nova has one peak in summer and one trough in winter. Therefore, we conclude that one X-ray growth band is formed every winter in $A$. colbecki, as already shown for many other scallop species (e.g. Tan et al., 1988; Schick et al., 1988; Dare and Deith, 1990; Lasta et al., 2001). In our example shells (Fig. 2), there are some $\delta^{18} \mathrm{O}$ peaks without corresponding X-ray growth bands, i.e. in some winters, no distinguishable band may be formed. This may cause underestimation of true age, but the large number of shells $(N=25)$ used here compensates this potential bias.

\subsection{Growth of A. colbecki}

Previously published estimates of VBGF growth parameter values in $A$. colbecki are not directly comparable to our data because those studies (e.g. Ralph and Maxwell, 1977; Stockton, 1984; Berkman, 1990; Pranovi et al., 1994) (i) applied the specialized VBGF only, where the "shape" parameter $D$ is set equal to 1 , or (ii) were obtained from sizeincrement data (Chiantore et al., in press) (for a detailed discussion, see Francis, 1988). A common plot (Fig. 5), however, shows that all these growth models form a rather dense 


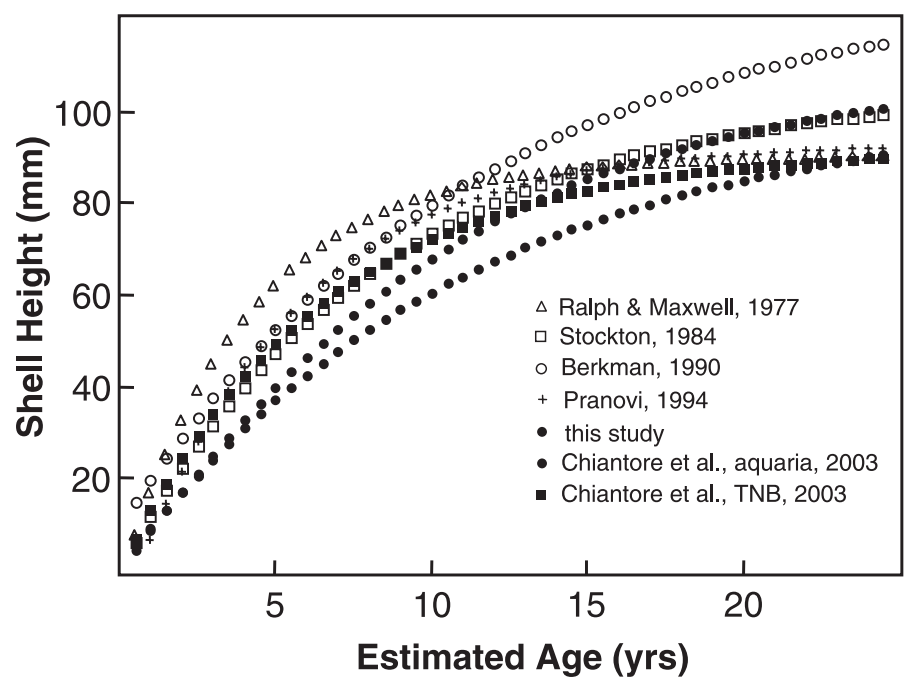

Fig. 5. Von Bertalanffy growth functions of $A$. colbecki populations published by various authors. VBGF parameters: Ralph and Maxwell (1977), $H_{\infty}=90 \mathrm{~mm}, K=0.24, D$ set to 1; Stockton (1984), $H_{\infty}=105 \mathrm{~mm}$, $K=0.12, D$ set to 1 ; Berkman (1990), $H_{\infty}=128 \mathrm{~mm}, K=0.09, D$ set to 1; Pranovi et al. (1994), $H_{\infty}=93 \mathrm{~mm}$, $K=0.19, D$ set to 1 ; Chiantore et al. (in press, TNB), $H_{\infty}=92 \mathrm{~mm}, K=0.154, D$ set to 1 ; Chiantore et al. (in press, aquaria), $H_{\infty}=101 \mathrm{~mm}, K=0.09, D$ set to 1 ; this study, $H_{\infty}=108.86 \mathrm{~mm}, K=0.114, D=1.284$.

cluster of quite similar curves. Obvious differences may be caused partially by the application of the less reliable visual shell growth band analysis (Stockton, 1984), partially by differences in population age structure, and partially by differences in environmental conditions between sites.

The index $P=\log \left(K M_{\infty}\right)$, where $K$ is the growth rate constant $K$ of the VBGF and $M_{\infty}$ is inferred from $H_{\infty}$, can be used to compare overall growth performance of different populations or species (Moreau et al., 1986). According to this measure, growth performance of scallops decreases with increasing latitude, and $A$. colbecki shows the lowest growth performance of all scallops investigated so far (Fig. 6a). In comparison to other Antarctic invertebrates, however, growth performance of $A$. colbecki appears rather high (Fig. 6b). Actually, besides the bivalve Laternula elliptica (King and Broderip, 1831) (Ralph and Maxwell, 1977; Urban and Mercuri, 1998), A. colbecki shows the highest values of all Antarctic species investigated to date.

\subsection{Production and productivity}

Size frequency distributions of the $A$. colbecki population from Terra Nova Bay show distinct annual differences (Fig. 1). This seems to be caused by extreme year-to-year variability in recruitment success (Chiantore et al., 2001, 2002). Insufficient nutrition of adults and of larvae during summer may be the major reason for recruitment failures (Cattaneo-Vietti et al., 1999). Hence, production data referring to a single season such as $1999 / 2000$ (Fig. 1g, $P_{\text {tot }}=305.51 \mathrm{~kJ} \mathrm{~m}^{-2}$ year $^{-1}, P_{\text {tot }} / B=0.251$ year $^{-1}$ ) are poor 


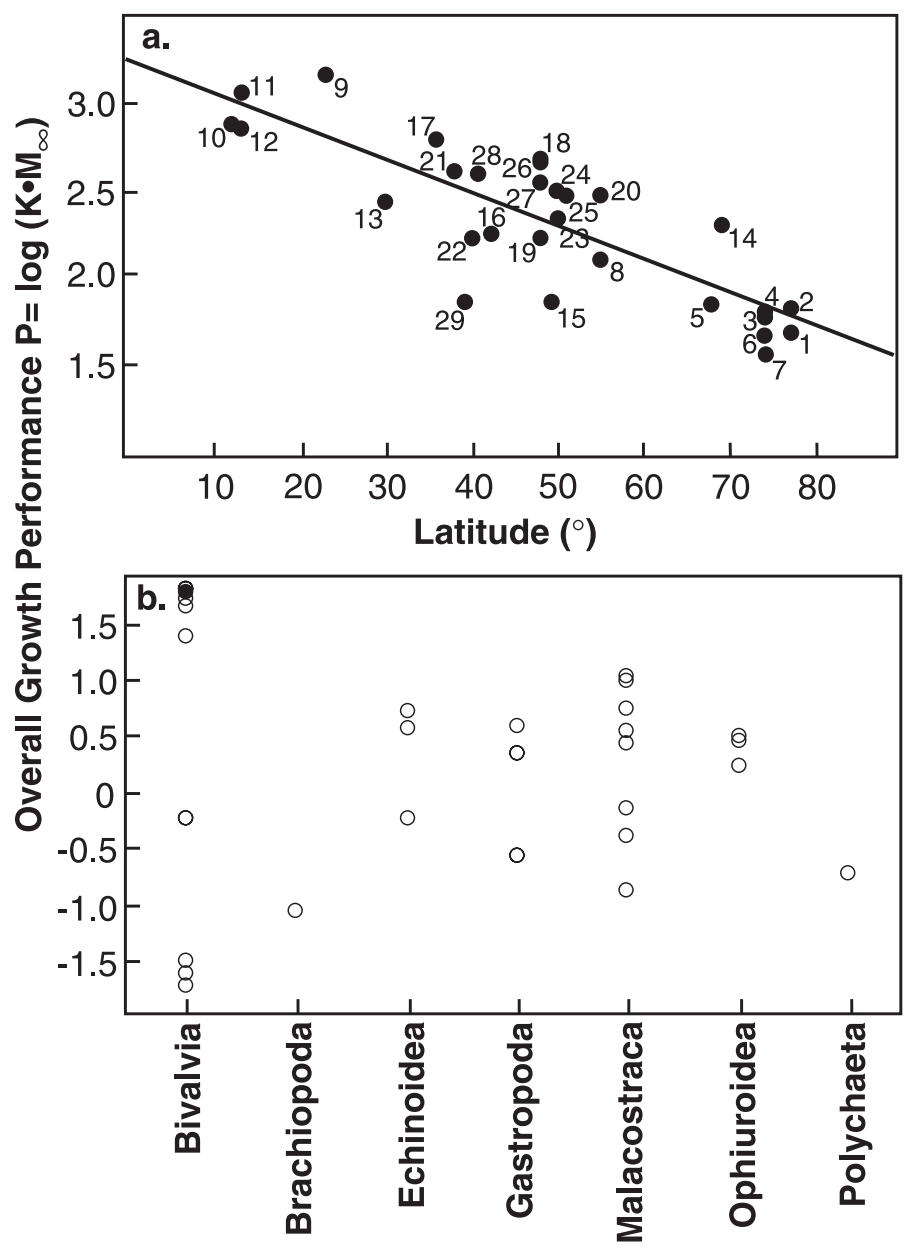

Fig. 6. Overall growth performance $\left(P=\log \left(K M_{\infty}\right)\right)$ in (a) scallop populations worldwide and (b) Antarctic invertebrates of different taxons compared with $A$. colbecki from this study (filled dot). Data sources. (a) 1-5: A. colbecki (1: Stockton, 1984; 2: Berkman, 1990; 3: this study; 4: Pranovi et al., 1994; 5: Ralph and Maxwell, 1977; 6: Chiantore et al., in press, wild population 7: Chiantore et al., in press, aquaria), 8: Aequipecten opercularis (Allison, 1994), 9: Amusium japonicum (Williams and Dredge, 1981), 10: Amusium pleuronectes (Nugranad, 1988, fidem Vakily, 1992), 11-13: Argopecten purpuratus (11: Yamashiro and Mendo, 1988; 12: Mendo and Jurado, 1993; 13: Tomicic and Kong, 1978, in Wolff, 1994), 14-15: Chlamys islandica (14: Vahl, 1981; 15: Naidu et al., 1982, in Orensanz et al., 1990), 16: Chlamys techuela (Orensanz, 1986), 17: Mizuhopecten yessoensis (Yoo et al., 1981), 18-20: Patinopecten caurinus (18: Haynes and Hitz, 1971, 19: MacDonald and Bourne, 1987; 20: Ignell and Haynes, 2000), 21: Pecten alba (Gwyther and McShane, 1988), 22: Pecten fumata (Fairbridge, 1953), 23-25: Pecten maximus (23: Dare and Deith, 1990; 24: Dare, 1991; 25: Allison, 1994), 2628: Placopecten magellanicus (26-27 MacDonald and Thompson, 1985, 1986; 28: Thouzeau et al., 1991), 29: Zygochlamys patagonica (Lasta et al., 2001). Regression line: $P=3.257-0.019$. latitude $\left(^{\circ}\right) ; N=29 ; R^{2}=0.686$. (b) Brey and Clarke (1993), Brey (1999), and references therein. 
representatives of the population steady-state, whereas estimates derived from a multiyear size frequency distribution (Fig. $1 \mathrm{~h}, P_{\text {tot }}=609.28 \mathrm{~kJ} \mathrm{~m}^{-2}$ year $^{-1}, P_{\text {tot }} / B=0.215$ year $^{-1}$ ) are more representative from a long-term point of view (Allen, 1971). The strongly leftskewed multiyear distribution (Fig. 1h) is typical of slow growing, long-lived species and populations with irregular recruitment events (e.g. Brey et al., 1990, 1995b; Arntz et al., 1992).

So far, this study presents the first attempt to estimate the gonad productivity of $A$. colbecki which is based on differences between gonadal mass before and after spawning. This approach assumes that all materials stored during the mass increase in summer are devoted to reproduction, which may not be true. Precise spawning times are unknown. Berkman et al. (1991) presume spawning in McMurdo Sound during austral spring, while Cattaneo-Vietti et al. (1997) suggest that gonad maturation takes place in late summer. $P_{\mathrm{S}} / B$ as well as $P_{\text {tot }} / B$ of $A$. colbecki are at the lower end of the range reported for scallops, even when the scaling effect of average individual body mass is taken into account (Fig. 7). This coincides well with the comparatively low overall growth performance (Fig. 6) and indicates that the temperature-induced low metabolism of individual A. colbecki (Heilmayer et al., 2002) is reflected at the level of population turnover, as also found in other Antarctic invertebrates (Brey and Clarke, 1993; Brey et al., 1995a,b; Urban and Mercuri, 1998).

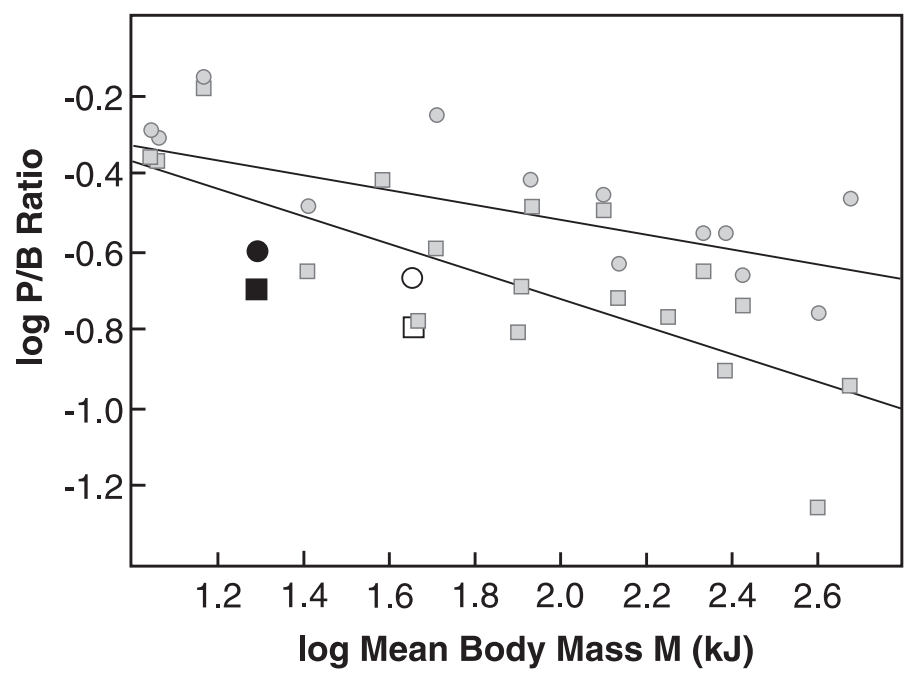

Fig. 7. Annual $P_{\mathrm{S}} / B$ ratio (circles) and $P_{\text {tot }} / B$ ratio (squares) versus mean body mass $(\mathrm{kJ})$ in scallop populations. Data sources: A. colbecki (Stockton, 1984; Berkman, 1990), C. islandica (Vahl, 1981), Comptopallium radula (Lefort, 1994), Crassadoma gigantea (MacDonald et al., 1991), Mimachlamys gloriosa (Lefort, 1994), Mimachlamys varia (Shafee and Conan, 1984), Mizuhopecten yessoensis (Goliko and Scarlato, 1970), Patinopecten caurinus (MacDonald and Bourne, 1987), Placopecten magellanicus (MacDonald and Thompson, 1985, 1986; Claereboudt and Himmelman, 1996), Zygochlamys patagonica (Lasta et al., 2001). Black symbols: A. colbecki, this studyseason 1999/2000, open symbols: this study - based on multiyear SFD. Regression lines: $(\operatorname{dots}) \log \left(P_{\mathrm{S}} / B\right)=$ $-0.024-0.345 \log (M) ; N=20 ; R^{2}=0.536 ; P<0.01$ : (squares) $\log \left(P_{\text {tot }} / B\right)=-0.146-0.186 \log (M) ; N=15$; $R^{2}=0.383 ; P<0.05$. 


\subsection{Ecological significance}

The ecological significance of $A$. colbecki in the Terra Nova Bay ecosystem is defined by its position in the food web and by the amount of energy flowing through the population. As A. colbecki is a suspension feeder, it represents a direct link between pelagic primary production and benthic or demersal higher level predators. Known predators of $A$. colbecki are $T$. bernacchii and invertebrates such as $N$. eatoni and Odontaster validus (Vacchi et al., 2000). According to our results, about $433 \mathrm{~kJ} \mathrm{~m} \mathrm{~m}^{-2}$ year $^{-1}$ (ca. $9.5 \mathrm{~g} \mathrm{C} \mathrm{m}^{-2}$ year $^{-1}$ ) are transferred from the scallop to its predators.

The question how much $A$. colbecki in Terra Nova Bay consumes and whether this dense population living in the euphotic zone may be able to control primary production as already observed in populations from temperate waters (see Smaal and Prins, 1993; Dolmer, 2000) is more difficult to answer. Of the simple energy budget (see Crisp, 1984):

\section{Consumption $=$ Production + Respiration + Egestion + Excretion}

total production, $609 \mathrm{~kJ} \mathrm{~m}^{-2}$ year ${ }^{-1}$, and respiration, $1558 \mathrm{~kJ} \mathrm{~m}^{-2}$ year $^{-1}$ (whole year average, calculated from measurements of summer and winter metabolism, Heilmayer et al., 2002), are known, i.e. annual assimilation amounts to $2167 \mathrm{~kJ} \mathrm{~m}^{-2}$ year $^{-1}$ (all estimates referring to the long-term average population structure, Fig. 1h). Chiantore et al. (1998) found the assimilation efficiency $(100 \times$ Assimilation/Consumption $)$ of $A$. colbecki to be about $36 \%$; hence, the annual consumption of the Terra Nova Bay population is about $6000 \mathrm{~kJ} \mathrm{~m}^{-2}$ year $^{-1}$ (ca. $131 \mathrm{~g} \mathrm{C} \mathrm{m}^{-2}$ year $^{-1}$ ). Using Albertelli et al.'s (1998) estimate of daily sedimentation rate in Terra Nova Bay, $0.36 \mathrm{~g} \mathrm{C} \mathrm{m}^{-2}$ day $^{-1}$, and assuming a productive phase of about 60 days per year (Albertelli et al., 1998), the annual input to the benthos is about $1000 \mathrm{~kJ} \mathrm{~m}^{-2}$ year $^{-1}\left(22 \mathrm{~g} \mathrm{C} \mathrm{m}^{-2}\right.$ year $\left.^{-1}\right)$, i.e. about $17 \%$ of the food required by the $A$. colbecki population. Even if we allow for distinct interannual variability of production and duration of productive phase, this is far too low to maintain the $A$. colbecki population investigated. Potential additional food sources may be (i) ice algae, (ii) macroalgal detritus, or (iii) lateral advection of organic matter from the open Ross Sea. Ice algae can contribute significantly to total primary production (Spindler and Dieckmann, 1991; Melnikov, 1998), but their production in Terra Nova Bay has not yet been determined. The same is true for macroalgal detritus, which is known to be produced in large quantities on littoral rocky shores (Berkman et al., 1986; Albertelli et al., 1998). Lateral advection of organic matter is supposed to play a significant role in Antarctic coastal and shelf systems (Dayton, 1990; Brey et al., 1993, 1995a; Arntz et al., 1994), and the open Ross Sea is a potential source of matter laterally advected to Terra Nova Bay. With primary production rates up to $180 \mathrm{~g} \mathrm{C} \mathrm{m}^{-2}$ year $^{-1}\left(\sim 8200 \mathrm{~kJ} \mathrm{~m}^{-2}\right.$ year $^{-1}$ ) and average sedimentation rates of 97\% (Fabiano et al., 1997; Saggiomo et al., 2000), the Ross Sea is considered to be the most productive system in the Southern Ocean (Smith et al., 1996).

Further quantitative and qualitative studies of whole year sedimentation in TNB will answer open questions and may be the key to explain the interannual variability in $A$. colbecki recruitment and population structure. 


\section{Acknowledgements}

This research could only be realised thanks to the support by the Italian National Programme for Antarctic Research (PNRA) and the Alfred Wegener Institute for Polar and Marine Research. We are grateful to Ute Jacob and Michael Seebeck (AWI) for preparation of X-ray photographs as well as to Katrin Blancke and Andreas Mackensen (AWI) for technical support in stable isotope analysis. We are indebted to P.A. Berkman for a critical discussion of the manuscript. Sandra Shumway and an anonymous referee are acknowledged for many helpful comments and linguistic corrections. [SS]

\section{References}

Albertelli, G., Cattaneo-Vietti, R., Chiantore, M., Pusceddu, A., Fabiano, M., 1998. Food availability to an Adamussium bed during the Austral Summer 1993/1994 (Terra-Nova Bay, Ross Sea). J. Mar. Syst. 17, $425-434$.

Allen, K.R., 1971. Relation between production and biomass. J. Fish. Res. Board Can. 28, 1537-1581.

Allison, E.H., 1994. Seasonal growth models for great scallops (Pecten maximus (L.)) and queen scallops (Aequipecten opercularis (L.)). J. Shellfish Res. 13, 555-564.

Arntz, W.E., Brey, T., Gerdes, D., Gorny, M., Gutt, J., Hain, S., 1992. Patterns of life history and population dynamics of benthic invertebrates under the high Antarctic conditions of the Weddell Sea. In: Colombo, G., Ferrari, I., Ceccherelli, V.U., Rossi, R. (Eds.), Marine Eutrophication and Population Dynamics, with a Special Section on the Adriatic Sea. 25th European Marine Biology Symposium. Olsen \& Olsen, Fredensborg, Denmark, pp. 221-230.

Arntz, W.E., Brey, T., Gallardo, V.A., 1994. Antarctic zoobenthos. Oceanogr. Mar. Biol. Ann. Rev. 32, 241 - 304.

Barrera, E., Tevesz, M.J.S., Carter, J.G., 1990. Variations in oxygen and carbon isotopic compositions and microstructure of the shell of Adamussium colbecki (Bivalvia). Palaios 5, 149-159.

Berkman, P.A., 1990. The population biology of the Antarctic scallop, Adamussium colbecki (Smith, 1902) at New Harbor, Ross Sea. In: Kerry, K.R., Hempel, G. (Eds.), Antarctic Ecosystems. Ecological Change and Conservation. Springer, Berlin, NY, pp. 281-288.

Berkman, P.A., Marks, D.S., Shreve, G.P., 1986. Winter sediment resuspension in McMurdo Sound, Antarctica, and its ecological implications. Polar Biol. 6, 1-3.

Berkman, P.A., Waller, T., Alexander, S.P., 1991. Unprotected larval development in the Antarctic scallop Adamussium colbecki (Mollusca: Bivalvia: Pectinidae). Antarct. Sci. 3, 151-157.

Brey, T., 1999. Growth performance and mortality in aquatic macrobenthic invertebrates. Adv. Mar. Biol. 35, $153-223$.

Brey, T., 2001. Population dynamics in benthic invertebrates. A Virtual Handbook. Alfred Wegener Institute for Polar and Marine Research, Germany. Version 1.2. http://www.awi-bremerhaven.de/Benthic/Ecosystem/ FoodWeb/Hand book/main.html.

Brey, T., Clarke, A., 1993. Population dynamics of marine benthic invertebrates in Antarctic and subantarctic environments: are there unique adaptations. Antarct. Sci. 5, 253-266.

Brey, T., Gerdes, D., 1997. Is Antarctic benthic biomass really higher than elsewhere? Antarct. Sci. 9, $266-267$.

Brey, T., Mackensen, A., 1997. Stable isotopes prove shell growth bands in the Antarctic bivalve Laternula elliptica to be formed annually. Polar Biol. 17, 465-468.

Brey, T., Rumohr, H., Ankar, S., 1988. Energy content of macrobenthic invertebrates: general conversion factors from weight to energy. J. Exp. Mar. Biol. Ecol. 117, 271-278.

Brey, T., Arntz, W.E., Pauly, D., Rumohr, H., 1990. Arctica (Cyprina) islandica in Kiel Bay (Western Baltic): growth, production and ecological significance. J. Exp. Mar. Biol. Ecol. 136, 217-235.

Brey, T., Starmans, A., Magiera, U., Hain, S., 1993. Lissarca notorcadensis (Bivalvia: Philobryidae) living on Notocidaris sp. (Echinoida: Cidaroidea): population dynamics in limited space. Polar Biol. 13, 89-95.

Brey, T., Pearse, J., Basch, L., McClintock, J., Slattery, M., 1995a. Growth and production of Sterechinus neumayeri (Echinoidae: Echinodermata) in McMurdo Sound, Antarctica. Mar. Biol. 124, 279-292. 
Brey, T., Peck, L.S., Gutt, J., Hain, S., Arntz, W.E., 1995b. Population dynamics of Magellania fragilis, a brachipod dominating a mixed bottom macro-benthic assemblage on the Antarctic shelf. J. Mar. Biol. Assoc. U.K. 95, 857-869.

Calow, P., 1983. Life-cycle patterns and evolution. In: Russel-Hunter, W.D. (Ed.), The Mollusca. Ecology, vol. 6. Academic Press, Boston, pp. 649-678.

Cattaneo-Vietti, R., Chiantore, M., Albertelli, G., 1997. The population structure and ecology of the Antarctic scallop Adamussium colbecki (Smith, 1902) at Terra Nova Bay (Ross Sea, Antarctica). Sci. Mar. 61, 14-24.

Cattaneo-Vietti, R., Chiantore, M., Misic, C., Povero, P., Fabiano, M., 1999. The role of pelagic-benthic coupling in structuring littoral benthic communities at Terra Nova Bay (Ross Sea) and in the Straits of Magellan. Sci. Mar. 63, 113-121.

Chiantore, M., Cattaneo-Vietti, R., Albertelli, G., Misic, C., Fabiano, M., 1998. Role of filtering and biodeposition by Adamussium colbecki in circulation of organic matter in Terra Nova Bay (Ross Sea, Antarctica). J. Mar. Syst. 17, 411-424.

Chiantore, M., Cattaneo-Vietti, R., Albertelli, G., 2000. The population structure and ecology of the Antarctic scallop Adamussium colbecki in Terra Nova Bay. In: Faranda, F.M., Guglielmo, L., Ianora, A. (Eds.), Ross Sea Ecology: Italiantartide Expeditions (1987-1995). Springer, Berlin, pp. 563-573.

Chiantore, M., Cattaneo-Vietti, R., Berkman, P.A., Nigro, M., Vacchi, M., Schiaparelli, S., Albertelli, G., 2001. Antarctic scallop (Adamussium colbecki) spatial population variability along the Victoria Land Coast, Antarctica. Polar Biol. 24, 139-143.

Chiantore, M., Cattaneo-Vietti, R., Elia, L., Guidetti, M., Antonini, M., 2002. Reproduction and condition of the scallop Adamussium colbecki (Smith, 1902), the sea-urchin Sterechinus neumayeri (Meissner 1900) and the sea-star Odontaster validus Koehler 1911 at Terra Nova Bay (Ross Sea): different strategies related to interannual variations in food availability. Polar Biol. 25, 251-255.

Chiantore, M., Cattaneo-Vietti, R., Heilmayer, O., 2003. Antarctic scallop (Adamussium colbecki) annual growth rate at Terra Nova Bay. Polar Biol. (in press).

Claereboudt, M.R., Himmelman, J.H., 1996. Recruitment, growth and production of giant scallops (Placopecten magellanicus) along an environmental gradient in Baie des Chaleurs, eastern Canada. Mar. Biol. 124, 661 -670.

Crisp, D.J., 1984. Energy flow measurements. In: Holme, N., McIntoye, A.D. (Eds.), Methods for the Study of Marine Benthos. Blackwell, Oxford, pp. 284-372.

Dare, P.J., 1991. Use of external shell microgrowth patterns for determining growth and age in the scallop Pecten maximus. Actes Colloq.-IFREMER 17, 211-218.

Dare, P.J., Deith, M.R., 1990. Age determination of scallops, Pecten maximus (Linnaeus, 1758), using stable oxygen isotope analysis, with some implications for fisheries management in British waters. In: Shumway, S.E., Sandifer, P.A. (Eds.), An International Compendium of Scallop Biology and Culture. World Aquaculture Society, Baton Rouge, LA, pp. 118-133.

Dayton, P.K., 1990. Polar benthos. In: Smith Jr., W.O. (Ed.), Polar Oceanography, Part B. Academic Press, London, pp. 631-685.

Dolmer, P., 2000. Algal concentration profiles above mussel beds. J. Sea Res. 43, $113-119$.

Epstein, S., Buschbaum, R., Lowenstam, H.A., Urey, H.C., 1953. Revised carbonate-water isotopic temperature scale. Geol. Soc. Amer. Bull. 64, 1315-1326.

Fabiano, M., Chiantore, M., Povero, P., Cattaneo-Vietti, R., Pusceddu, A., Misic, C., Albertelli, G., 1997. Shortterm variations in particulate matter flux in Terra Nova Bay, Ross Sea. Antarct. Sci. 9, $143-149$.

Fairbridge, W.S., 1953. A population study of the Tasmanian "commercial" scallop Notovola meridionalis (Tate) (Lamellibranchi, Pectinidae). Aust. J. Mar. Freshw. Res. 4, 1-40.

Francis, R.I.C.C., 1988. Are growth parameters estimated from tagging and age-length data comparable? Can. J. Fish. Aquat. Sci. 45, 936-942.

Goliko, A.N., Scarlato, O.A., 1970. Abundance, dynamics and production properties of edible bivalves Mizuhopecten yessoensis and Spisula sachalinensis related to the problem of organisation of controllable submarine farms at the western shores of the Sea of Japan. Helgol. Mar. Res. 20, 498-513.

Gwyther, D., McShane, P.E., 1988. Growth rate and natural mortality of the scallop Pecten alba Tate in Port Phillips Bay, Australia, and evidence for changes in growth rate after a 20-year period. Fish. Res. 6, 347-361.

Haynes, E.B., Hitz, C.R., 1971. Age and growth of the giant Pacific sea scallop, Patinopecten caurinus, from the Strait of Georgia and outer Washington coast. J. Fish. Res. Board Can. 28 (9), 1335-1341. 
Heilmayer, O., Pörtner, H.O., Brey, T., 2002. Growth, production and respiration in scallops. Comp. Biochem. Physiol. 132A, S20.

Hut, G., 1987. Stable isotope reference samples for geochemical and hydrological investigations. International Atomic Energy Agency, Report 42 (Vienna, Sept. 16-18).

Ignell, S., Haynes, E., 2000. Geographic patterns in growth of the giant Pacific Sea scallop, Patinopecten caurinus. Fish. Bull. 98, 849-853.

Jarre-Teichmann, A., Brey, T., Bathmann, U.V., Dahm, C., Dieckmann, G.S., Gorny, M., Pages, F., Plötz, J., Schnack-Schiel, S., Stiller, M., Arntz, W.E., 1997. Trophic flows in the benthic shelf community of the eastern Weddell-Sea. In: Battaglia, B., Valencia, J., Walton, D.W.H. (Eds.), Antarctic Communities: Species, Structure and Survival. Cambridge Univ. Press, Cambridge, pp. 118-134.

Krantz, D.E., Jones, D.S., Williams, D.F., 1984. Growth rates of the sea scallop, Placopecten magellanicus, determined from the super(18)O/super(16)O record in shell calcite. Biol. Bull. Mar. Biol. Lab., Woods Hole $167,186-199$.

Krantz, D.E., Williams, F.D., Jones, D.S., 1987. Ecological and palaeoenvironmental information using stable isotope profiles from living and fossil molluscs. Palaeogeogr. Palaeoclimatol. Palaeoecol. 58, 249-266.

Lasta, M., Valero, J., Brey, T., Bremec, C., 2001. Zygochlamys patagonica (King and Broderip) beds on the Argentinian shelf: Part II. Population dynamics of Zygochlamys patagonica. Arch. Fish. Mar. Res. 49, $125-137$.

Lefort, Y., 1994. Growth and mortality of the tropical scallops: Annachlamys flabellata (Bernardi), Comptopallium radula (Linne) and Mimachlamys gloriosa (Reeve) in the southwest lagoon of New Caledonia. J. Shellfish Res. 13, 539-546.

Lohmann, K.C., Berkman, P.A., Marcano, M.C., 2001. A high resolution $d^{18} \mathrm{O}$ record of growth banding in Adamussium colbecki: a proxy for reconstruction of coastal salinities and continental temperatures on annual to century time scales. In: Berkman, P.A., Tipton-Everett, L.R. (Eds.), Latitudinal Ecosystem (LAT-ECO) Responses to Climate Across Victoria Land, Antarctica. Report of a National Science Foundation Workshop. BPRC Report No. 20, Byrd Polar Research Center, The Ohio State University, Columbus, Ohio, pp. 96-98.

Loo, L.O., Rosenberg, R., 1989. Bivalve suspension-feeding dynamics and benthic-pelagic coupling in an eutrophicated marine bay. J. Exp. Mar. Biol. Ecol. 130, 253-276.

MacDonald, B.A., Bourne, N.F., 1987. Growth, reproductive output, and energy partitioning in weathervane scallops, Patinopecten caurinus, from British Columbia. Can. J. Fish. Aquat. Sci. 44, 152-160.

MacDonald, B.A., Thompson, R.J., 1985. Influence of temperature and food availability on the ecological energetics of the giant scallop Placopecten magellanicus: II. Reproductive output and total production. Mar. Ecol. Prog. Ser. 25, 295-303.

MacDonald, B.A., Thompson, R.J., 1986. Production, dynamics and energy partitioning in two populations of the giant scallop Placopecten magellanicus (Gmelin). J. Exp. Mar. Biol. Ecol. 101, 285-299.

MacDonald, B.A., Thompson, R.J., Bourne, N.F., 1991. Growth and reproductive energetics of three scallop species from British Columbia (Chlamys hastata, Chlamys rubida and Crassadoma gigantea). Can. J. Fish. Aquat. Sci. 48, 215-221.

Marshall, J.D., Pirrie, D., Nolan, C., 1993. Oxygen stable isotope composition of skeletal carbonates from living Antarctic marine invertebrates. Antarct. Spec. Topic, 81-84.

Marshall, J.D., Pirrie, D., Clarke, A., Nolan, C.P., Sharman, J., 1996. Stable-isotopic composition of skeletal carbonates from living Antarctic marine invertebrates. Lethaia 29, 203-212.

McConnaughey, T.A., Burdett, J., Whelan, J.F., Paull, C.K., 1997. Carbon isotopes in biological carbonates: respiration and photosynthesis. Geochim. Cosmochim. Acta 61, 611-622.

Melnikov, I.A., 1998. Winter production of sea ice algae in the western Weddell Sea. J. Mar. Syst. 17, $195-205$.

Mendo, J., Jurado, E., 1993. Length-based growth parameter estimates of the Peruvian scallop (Argopecten purpuratus). Fish. Res. 15, 357-367.

Merrill, A.S., Posgay, J.A., Nichy, F.E., 1965. Annual marks on the shell and ligament of the sea scallop (Placopecten magellanicus). Fish. Bull. 65, 299-311.

Mistri, M., Rossi, R., Fano, E.A., 2001. Structure and secondary production of a soft bottom macrobenthic community in a brackish lagoon (Sacca di Goro, north-eastern Italy). Estuar. Coast. Shelf Sci. 52, 605-616.

Moreau, J., Bambino, C., Pauly, D., 1986. Indices of overall growth performance of 100 tilapia (Cichlidae) populations. In: MacLean, J.L., Dizon, L.B., Hosillos, L.V. (Eds.), The First Asian Fisheries Forum. Asian Fisheries Society, Manila, Philippines, pp. 201-206. 
Naidu, K.S., Cahill, F.M., Lewis, D.B., 1982. Status and assessment of the Iceland scallop Chlamys islandica in the northeasten Gulf of St. Lawrence. CAFSAC Res. Doc. 82/02. 62 pp.

Nugranad, J., 1988. Preliminary report on the growth, mortality and recruitment of the Asian moon scallop Amusium pleuronectes in Koh Chang (Koh Kood area), eastern Gulf of Thailand. (unpublished report).

Orensanz, J.M., 1986. Size, environment, and density: the regulation of a scallop stock and its management implications. Can. Spec. Publ. Fish. Aquat. Sci. 92, 195-227.

Orensanz, J.M., Parma, A.M., Ibribarne, O.O., 1990. Population dynamics and management of natural stock. In: Shumway, S.E. (Ed.), Scallops: Biology, Ecology and Aquaculture. Elsevier, New York, pp. 625-714.

Picco, P., Bergamasco, A., Demicheli, L., Manzella, G., Meloni, R., Paschini, E., 2000. Large-scale circulation features in the central and western Ross Sea (Antarctica). In: Faranda, F.M., Guglielmo, L., Ianora, A. (Eds.), Ross Sea Ecology: Italiantartide Expeditions (1987-1995). Springer, Berlin, pp. 95-105.

Povero, P., Petrillo, M., 2000. Flussi e sostanza organica. Raporto sulla Campagna Antarctica Estate Australe 1999-2000, 86-88.

Pranovi, F., Marcato, S., Zanellato, R., 1994. Analisi biometriche e biologia di popolazione del mollusco antartico Adamussium colbecki a Baia Terra Nova, Mare di Ross. Atti Dell' Istituto Veneto Di Scienze Lettere Ed Arti Tomo CLII (1993-1994) 152, 123-136.

Ralph, R., Maxwell, J.G.H., 1977. Growth of two antarctic lamellibranchs: Adamussium colbecki and Laternula elliptica. Mar. Biol. 42, 171-175.

Richardson, C.A., 2001. Molluscs as archives of environmental change. Oceanogr. Mar. Ann. Rev. 39, 103-164.

Saggiomo, V., Carrada, G.C., Mangoni, O., Marino, D., D’Alcalà, M.R., 2000. Ecological and physiological aspects of primary production in the Ross Sea. In: Faranda, F.M., Guglielmo, L., Ianora, A. (Eds.), Ross Sea Ecology: Italiantartide Expeditions (1987-1995). Springer, Berlin, pp. 247-258.

Schick, D.F., Shumway, S.E., Hunter, M.A., 1988. A comparison of growth rate between shallow water and deep water populations of scallops, Placopecten magellanicus (Gmelin, 1791) in the Gulf of Maine. Am. Malacol. Bull. $6,1-8$.

Shafee, M.S., Conan, G., 1984. Energetic parameters of a population of Chlamys varia (Bivalvia: Pectinidae). Mar. Ecol. Prog. Ser. 18, 253-262.

Simstich, J., Müller-Lupp, T., Erlenkeuser, H., 2001. Schalen arktischer Bivalven als Datenspeicher jahreszeitlicher Schwankungen von Temperatur und Salzgehalt im Bodenwasser? Erste Ansätze aus Kara-und LaptevSee. Mitt. Kiel. Polarforsch. 17, 7-10.

Smaal, A.C., Prins, T.C., 1993. The uptake of organic matter and the release of inorganic nutrient by bivalve suspension feeder beds. In: Dame, R.F. (Ed.), Bivalve Filter Feeders in Estuarine and Coastal Ecosystem Processes. Springer, Heidelberg, pp. 273-298.

Smith, W.O., Nelson, D.M., Di Tullio, G.R., Leventer, A.R., 1996. Temporal and spatial patterns in the Ross Sea: phytoplankton biomass, elemental composition, productivity and growth rates. J. Geophys. Res. 101, $18455-18465$.

Spindler, M., Dieckmann, G.S., 1991. Das Meereis als Lebensraum. Spektrum Wiss. 2, 48-57.

Stockton, W.L., 1984. The biology and ecology of the epifaunal scallop Adamussium colbecki on the west side of McMurdo Sound. Antarct. Mar. Biol. 78, 171-178.

Tan, F.C., Cai, D., Roddick, D.L., 1988. Oxygen isotope studies on sea scallop, Placopecten magellanicus, from Browns Bank, Nova Scotia. Can. J. Fish. Aquat. Sci. 45, 1378-1386.

Thouzeau, G., Robert, G., Smith, S.J., 1991. Spatial variability in distribution and growth of juvenile and adult sea scallop Placopecten magellanicus (Gmelin) on eastern Georges Bank (Northwest Atlantic). Mar. Ecol. Prog. Ser. 74, 205-218.

Tomicic, J., Kong, I., 1978. Contribución al conocimiento del cultivo del ostion Argopecten purpuratus (Lamarck 1819), en la Bahía de Mejillones del Sur (Mollusca, Pelecypoda). Universidad De Chile, Inst. Invest. Ocean., Seminar Paper. (unpublished).

Urban, H.J., Mercuri, G., 1998. Population dynamics of the bivalve Laternula elliptica from Potter Cove, King George Island, South Shetland Islands. Antarct. Sci. 10, 153-160.

Vacchi, M., Cattaneo-Vietti, R., Chiantore, M., Dalu, M., 2000. Predator-prey relationship between the nototheniid fish Trematomus bernacchii and the Antarctic scallop Adamussium colbecki. Antarct. Sci. 12, 64-68.

Vahl, O., 1981. Energy transformation by the Iceland scallop, Chlamys islandica (O.F. Müller); from $70^{\circ} \mathrm{N}$ : I. The age-specific energy budget and net growth efficiency. J. Exp. Mar. Biol. Ecol. 53, 281-296. 
Vakily, J.M., 1992. Determination and comparison of bivalve growth, with emphasis on Thailand and other tropical areas. ICLARM Technical Report 36. 125 pp.

Weidman, C.R., Jones, G.A., Lohmann, K.C., 1994. The long-lived mollusc Arctica islandica: a new paleoceanographic tool for the reconstruction of bottom temperatures for the continental shelves of the northern North Atlantic Ocean. J. Geophys. Res. 99, 18305-18314.

Wildish, D., Kristmanson, D., 1997. Benthic Suspension Feeders and Flow. Cambridge Univ. Press, Cambridge. $407 \mathrm{pp}$.

Williams, M.J., Dredge, C.L., 1981. Growth of the saucer scallop Amusium japonicum balloti Habe in Central Eastern Queensland. Aust. J. Mar. Freshw. Res. 32, 657-666.

Wolff, M., 1994. Population dynamics, life histories and management of selected invertebrates of the SE Pacific upwelling system. Habilitation. University of Bremen, Bremen, Germany. 210 pp.

Yamashiro, C., Mendo, J., 1988. Crecimiento de la Concha de Abanico (Argopecten purpuratus) en la Bahia Independencia, Pisco, Perú. Memorias del 2do Congreso Latinoamericano Sobre Ciencias Del Mar, Lima, Perú, $163-168$.

Yoo, S.K., Ryu, H.-Y., Park, K.-Y., 1981. The growth of the cultured scallop Patinopecten yessoensis. Bull. Korea Fish. Soc. 14, 221-226. 